\title{
「医薬品に関する教育」が変える日本の医療
}

\author{
望月眞弓
}

\section{The Education on Medicines Will Change Japanese Medical Care}

\author{
Mayumi Mochizuki \\ Keio University Faculty of Pharmacy; 1-5-30 Shibakoen, Minato-ku, Tokyo 105-8512, Japan.
}

(Received August 25, 2013)

\begin{abstract}
Teaching the three health principles and proper use of medicines are the basis of education on medicines. Before seeking prescription drugs, day-to-day health management is important. It is also important to understand that if a minor ailment persists, self-treatment with over-the-counter medications should be attempted. Since medications are double-edged swords, their proper use is the responsibility of patients to minimize the risk and maximize the effectiveness. This awareness should be taught during education on how to use medicines. A better understanding of medicines and fostering awareness through education on medicines will contribute to reductions in healthcare costs and promote the health of patients when they participate in their own care and learn how to self-medicate.
\end{abstract}

Key words_ education of medicine; self-medication; over the counter medicines; health promotion

\section{1. 日本の医療の現状と将来}

財務省が公表したパンフレット「日本財政を考え る」1)では，20-64 歳人口の 65 歳以上人口に対する 比率は 2000 年では 3.6 であったものが，2025 年に は $1.8,2050$ 年には 1.2 となると予想されている (Fig. 1).すなわち, 現在は成人 7 人で高齢者 2 人 を支えている状況であるが，2050 年には 2 人で 2 人を支える時代となる可能性があることを意味して いる. Figure 22) に示すように社会保障給付費（年 金・医療・介護・福祉その他の給付費）の年次推移 は，90 年代から現在まで右肩上がりで推移してい る一方で, 社会保険料収入は 90 年代後半からほと んど変化しておらず収入を給付が大きく上回り，そ の差は地方税と国税で主として賄われている. 今後 は医療や介護に対する支出をいかに抑えることがで きるかが日本の将来の社会保障の中で重要な意味を 持ってくる。こうした中で，第二次健康日本 21 の 基本方針 $\left.{ }^{3}\right)$ （Table 1）では，健康寿命を延ばし，生 活習慣病の発症予防と重症化予防を具体化するに

The author declares no conflict of interest.

慶應義塾大学薬学部（干105-8512 東京都港区芝公園 1 $-5-30)$

e-mail: mochizuki-my@pha.keio.ac.jp

本総説は, 日本薬学会第 133 年会シンポジウム S30205 で発表した内容を中心に記述したものである.
Table 1. Japan Health Policy, Strategy and Action Plan 21 (by Ministry of Health, Labour and Welfare)

1. Extension of healthy life expectancy, and reduction of a healthy gap

2. Thoroughness of primary and secondary prevention of a lifestyle-related disease

3. Improvement and maintenance of the function to operate the social life

4. Development of social environment in order to support and protect the health

5. The improvement of the lifestyle and social environment on the nutrition/diet, the physical activity/exercise, the rest, the drinking alcohol, the smoking, and the health of the teeth/mouth

は，生活者自らが生活習慣に気をつけ，一次予防を 実践するという国民の意識の醸成や環境整備が重要 と指摘している.

2. これから大切になるセルフチェック, セルフ メディケーション

一次予防が重要になる時代においては, 健康三原 則を守り日常生活を正しくおくることが第一歩であ る. その上で, 定期的に健康診断を受けたり, 自己 検査薬を使つたりして自らの健康をセルフチェック することが求められる。「医薬品の教育」ではまず 


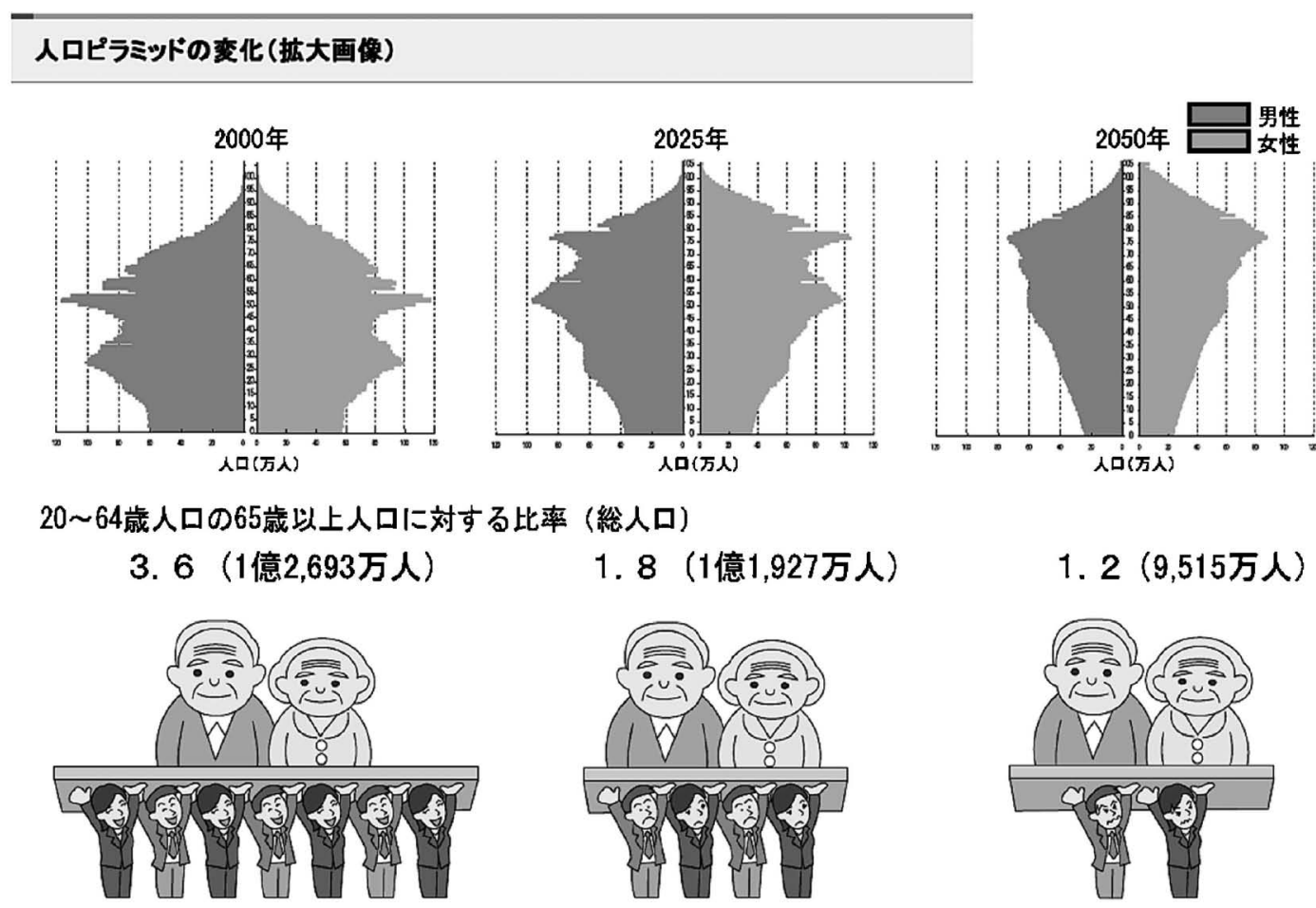

Fig. 1. Future Anticipation of the Age Pyramid and the Ratio of Elderly People Figure is quoted from the pamphlet of the Ministry of Finance, September 2012.

\section{年金や医癔関係の給付と財政の関係}

高齢化の進展に伴い、社会保障給付費が大きく伸びる一方で、社会保険料収入は横ばいで推移し、その 差額は拡大傾向にあります。この差額は主に、国や地方の税負担で賄われます。

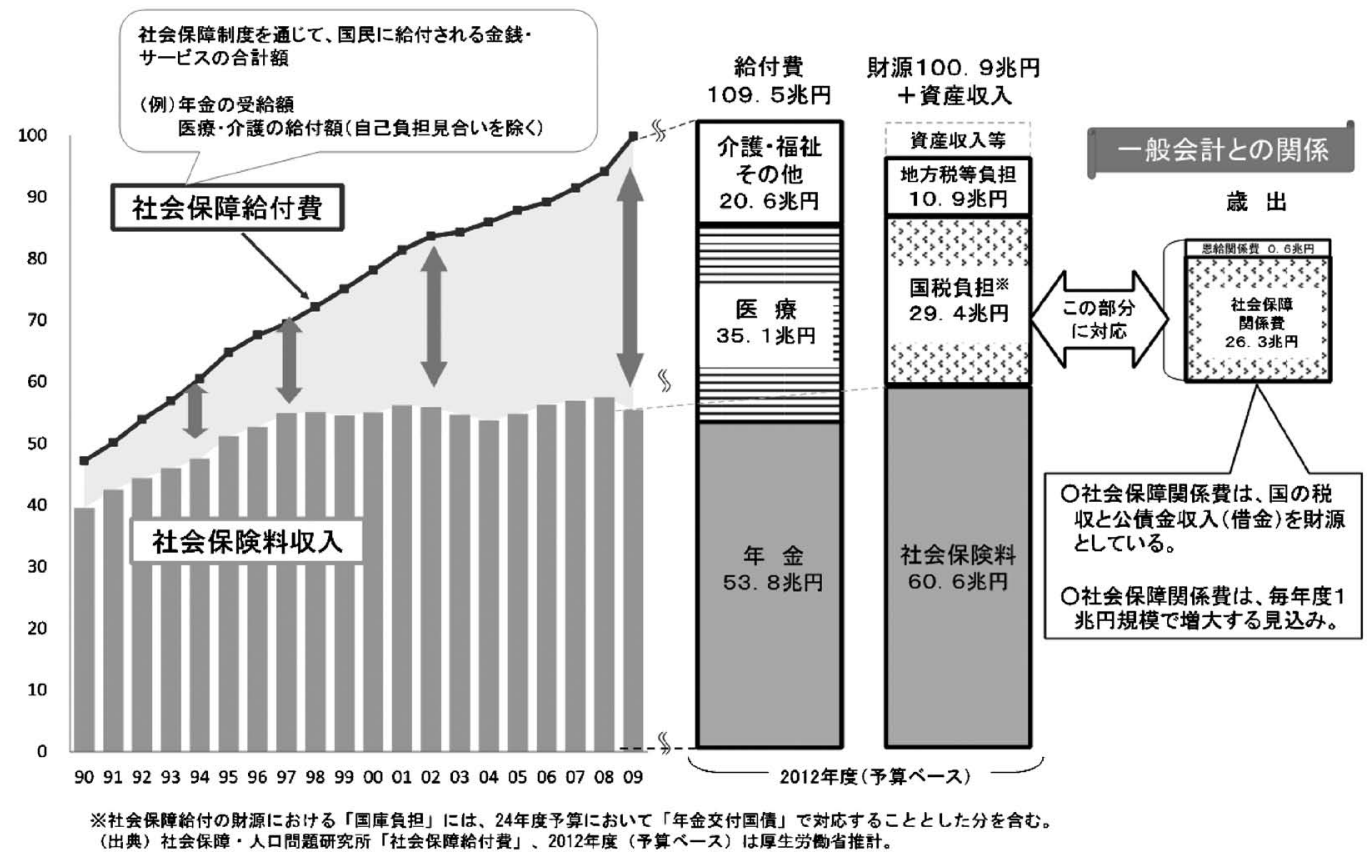

Fig. 2. Relation between Social Security Cost and Finances

Figure is quoted from Ministry of Finance HP http://www.zaisei.mof.go.jp/theme/theme6. 
- Self-medication is the practice whereby individuals treat their ailments and conditions with nonprescription drugs.

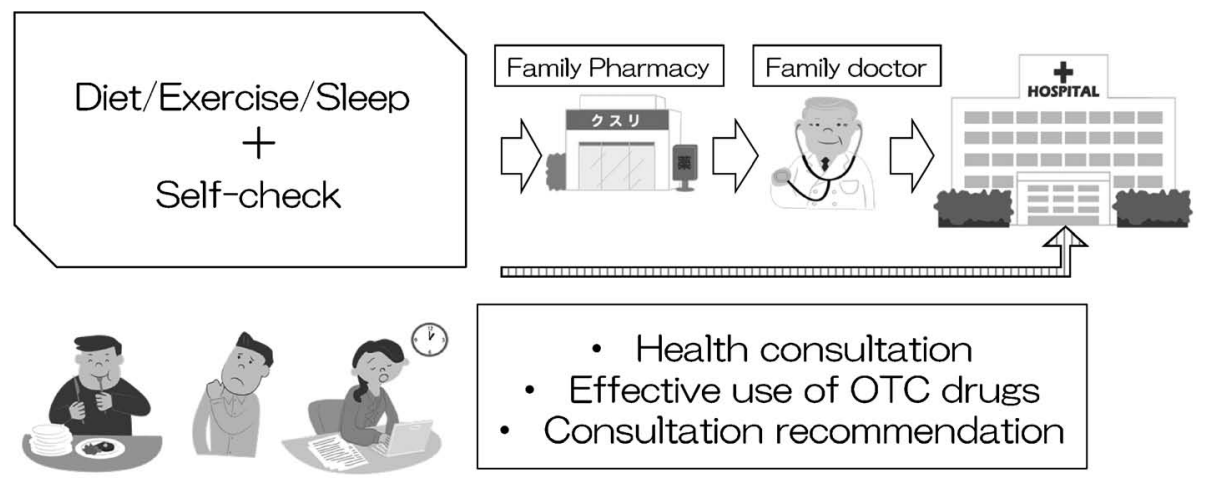

Fig. 3. Definition and Scheme of Self-medication

はじめに健康三原則の重要性を教え, それでも出て くる不調について，医薬品を使うと教える．軽度な 自らの不調は自分で手当するという概念は，セルフ メディケーションと言われ，これはこれからの日本 の医療を考える上でキーとなる概念である，セルフ メディケーションで重要な役割を果たすものに一般 用医薬品がある，消費者はまず薬局・薬店で健康相 談を行い，一般用医薬品を購入し，自己治療する か，自己治療の範囲を超えている場合は，医療機関 を受診する。薬局・薬店にはこうした際のゲート キーパーとしての役割を果たすことが求められる (Fig. 3)。それによって，本当に必要な患者に診療 を受ける機会が得られることになり，しかも早期に 治療を開始できる可能性も出てくる.

\section{3. セルフメディケーションを正しく実践するた} めに

医薬品は，主作用（ベネフィット） と副作用（リ スク）の両方を併せ持つ特殊な商品である（Fig. 4)。したがって，その使用者はベネフィットを最大 に，リスクを最小化するために，医薬品を正しく使 わなければならない。適切なセルフメディケーショ ンの実践には，医薬品を正しく使うという態度が醸 成されていることが必要になる。「医薬品の教育」 はそのために不可欠なものである，正しく使うとい うことには，自分に適した医薬品を選び，適した用 法用量で使うということだけでなく，今後増える慢 性疾患では継続して正しく服用すること，そして， 定期的に自らの状態をチェックするなどを心がける 必要がある。

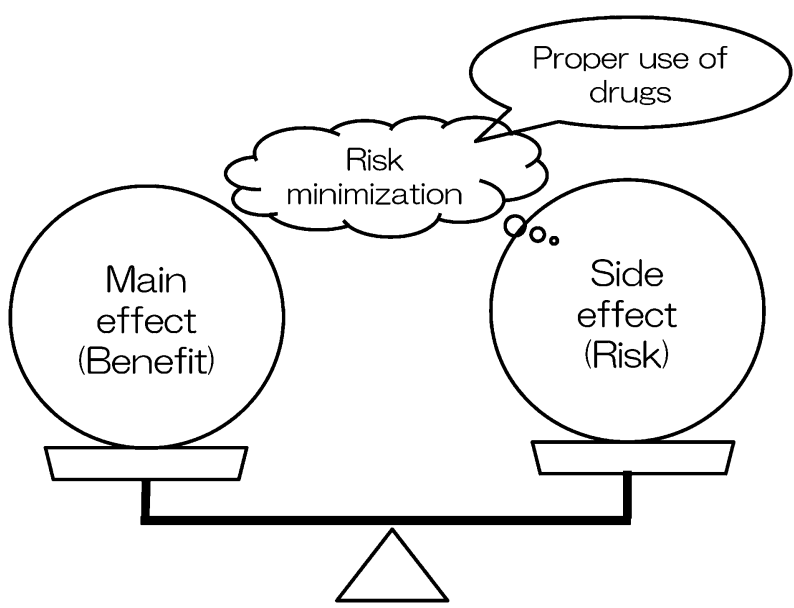

Fig. 4. Characteristic of Medicine

\section{4. 患者参加型医療の実現}

医薬品は生活習慣等の是正だけでは改善されない 体の不調に対して用いるものであって, 決して体調 不良であるからすべてのケースで使用するというも のではない，患者は，そうした医薬品の役割を理解 し, 医薬品による治療にも限界があることを認識し て医療を受ける心構えを持つ必要がある，現在，審 議中の薬事法改正案 (平成 25 年 5 月 24 日提出) ${ }^{4)}$ では，第一章総則第一条において，国の責務，都道 府県等の責務，医薬品等関連事業者の責務，医薬関 係者の責務，国民の役割が新設された。本法案は 2012 年 1 月に厚生科学審議会医薬品等制度改正検 討部会が，血液製剤による薬害肝炎事件を受けて, 「薬害」の再発防止を目標に薬事法等の改正に向け て行った提言に基づく．第一条の六「国民の役割」 
- Advancement in medical care $\rightarrow$ Increase of risk

- Evidence-based Medicine

- Highly informative society Information sharing

- Rights of patient $\rightarrow$ Informed consent/Self-decision making

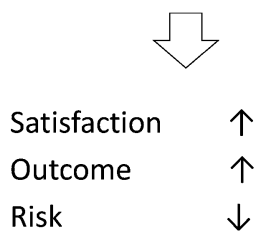

Fig. 5. Patient Participation in Medical Care

では，国民は医薬品等を適正に使用するとともに， これらの有効性及び安全性に関する知識と理解を深 めるよう努めなければならないとしている。この国 民の役割を果たすため,「医薬品の教育」はまさに 機を得たものである.

Figure 5 に示すように高度化が進むこれからの医 療は，リスクも高くなる可能性がある，患者は，医 薬品のベネフィットとリスクの両方について正確か つ十分な情報を医療者から得て共有し，自ら治療の 選択を決定することが求められる。 その際，分から ないことは納得できるまで説明を求めることは患者
に認められた権利である。その一方で，患者の役割 として医薬品は正しく使わなければならない，「医 薬品の教育」がこうした患者参加型の医療の実現に 大きく貢献することは間違いない。それによってよ り効果的，効率的な医療が実現し，医療費の削減に も寄与できると考える。

\section{REFERENCES}

1) Ministry of Finance: 〈http://www.mof.go.jp /budget/fiscal_condition/related_data/sy014/ sy014f.htm $\rangle$, cited August 22, 2013.

2) Ministry of Finance: $\langle$ http://www.zaisei.mof. go.jp/theme/theme6/>, cited August 22, 2013.

3) Ministry of Health, Labour and Welfare, Notification No. 430: 〈http://www.mhlw.go. jp/bunyakenkou/dl/kenkounippon21_01.pdf $\rangle$, cited August 22, 2013.

4) Ministry of Health, Labour and Welfare, Pharmaceutical Affairs Law amendment: 〈http://www.mhlw.go.jp / topics / bukyoku / soumu/houritu/dl/183-55.pdf $\rangle$, cited August 22, 2013. 